\title{
Factors that transformed maize productivity in Ethiopia
}

\author{
Tsedeke Abate $^{1} \cdot$ Bekele Shiferaw $^{2} \cdot$ Abebe Menkir $^{3} \cdot$ Dagne Wegary $^{4} \cdot$ Yilma Kebede $^{5}$. \\ Kindie Tesfaye $^{4} \cdot$ Menale Kassie $^{1} \cdot$ Gezahegn Bogale $^{6} \cdot$ Berhanu Tadesse $^{6} \cdot$ Tolera Keno $^{6}$
}

Received: 20 January 2015 / Accepted: 13 July 2015 / Published online: 26 July 2015

(C) The Author(s) 2015. This article is published with open access at Springerlink.com

\begin{abstract}
Maize became increasingly important in the food security of Ethiopia following the major drought and famine that occurred in 1984. More than 9 million smallholder households, more than for any other crop in the country, grow maize in Ethiopia at present. Ethiopia has doubled its maize productivity and production in less than two decades. The yield, currently estimated at $>3$ metric tons/ha, is the second highest in Sub-Saharan Africa, after South Africa; yield gains for Ethiopia grew at an annual rate of $68 \mathrm{~kg}$ /ha between 1990 and 2013, only second to South Africa and greater than Mexico, China, or India. The maize area covered by improved varieties in Ethiopia grew from $14 \%$ in 2004 to $40 \%$ in 2013, and the application rate of mineral fertilizers from 16 to $34 \mathrm{~kg} /$ ha during the same period. Ethiopia's extension worker to farmer ratio is $1: 476$, compared to 1:1000 for Kenya, 1:1603 for Malawi and 1:2500 for Tanzania. Increased use of improved maize varieties and mineral fertilizers, coupled with increased extension services and the absence of devastating droughts are the key factors promoting the accelerated growth in maize productivity in Ethiopia. Ethiopia took a homegrown
\end{abstract}

Tsedeke Abate

t.d.abate@cgiar.org

1 International Maize and Wheat Improvement Center (CIMMYT), Nairobi, Kenya

2 Partnership for Economic Policy, Nairobi, Kenya

3 International Institute for Tropical Agriculture (IITA), Ibadan, Nigeria

4 CIMMYT, Addis Ababa, Ethiopia

5 Bill \& Melinda Gates Foundation, Seattle, WA, USA

6 Ethiopian Institute of Agricultural Research (EIAR), Addis Ababa,, Ethiopia solutions approach to the research and development of its maize and other commodities. The lesson from Ethiopia's experience with maize is that sustained investment in agricultural research and development and policy support by the national government are crucial for continued growth of agriculture.

Keywords Success story $\cdot$ Maize revolution $\cdot$ Productivity gains $\cdot$ Food security $\cdot$ Input use $\cdot$ African agriculture

\section{Introduction}

Food security in Ethiopia, and elsewhere in Africa, is a major socio-political issue. Its economic wellbeing is also dependent on the success of its agriculture. Ethiopia has long suffered from food shortages and economic underdevelopment even though it is endowed with a wide range of crop and agroecological diversity. Maize, teff (Eragrostis tef), sorghum, wheat, and barley among cereals and enset (Ensete ventricosum) ("false banana") among "roots and tubers" provide the main calorie requirements in the Ethiopian diet. Crop productivity and production remained low and variable in the 90 s for the most part but there have been clear signs of change over the past decade.

Maize has expanded rapidly and transformed production systems in Africa as a popular and widely cultivated food crop since its introduction to the continent around 1500 A.D. (McCann 2005). Maize arrived in Ethiopia slightly later, around the late 17th century (Huffnagel 1961), and was mainly grown as a subsistence crop in the mid-altitudes (1500 $2000 \mathrm{~m}$ above sea level) in southern, south-central, and southwestern parts of the country. The production system in the 1960s and for the first quarter of 1970s was truly subsistence, the yields barely exceeding 1 metric ton (MT)/ha. The rate of 
growth for area declined following the great drought of 1974, and while there was expansion in the 1980s, the average annual yield was volatile and rarely exceeded 1.5 MT/ha. Maize production and its status in determining food security in the country received a major focus in the mid-1980s, particularly spurred by the 1984 devastating drought and the famine that followed. The wide adaptability of the crop and the potential to produce more calories and food per area of land cultivated than all major cereals grown in Ethiopia were important factors in considering maize as part of the national food security strategy, including its inclusion under the government-led intensive agricultural extension program.

With increased production driving market prices down, maize became more affordable (e.g., relative to other staples such as teff and wheat) to rural and urban consumers. It is now increasingly used both separately as well as in mixed flour with other more expensive cereals in traditional Ethiopian diets. Maize is the most important staple in terms of calorie intake in rural Ethiopia. The 2004/5 national survey of consumption expenditure indicated that maize accounted for $16.7 \%$ of the national calorie intake followed by sorghum $(14.1 \%)$ and wheat $(12.6 \%)$ among the major cereals (Berhane et al. 2011). Compared to the 1960s the share of maize consumption among cereals more than doubled to nearly $30 \%$ in the 2000 s, whereas the share of teff, a cereal that occupies the largest area of all crops in Ethiopia, declined from more than $30 \%$ to about $18 \%$ during the same period (Demeke 2012). ${ }^{1}$

The popularity of maize in Ethiopia is partly because of its high value as a food crop as well as the growing demand for the stover as animal fodder and source of fuel for rural families. Approximately $88 \%$ of maize produced in Ethiopia is consumed as food, both as green and dry grain. Maize for industrial use has also supported growing demand. Very little maize is currently used as feed but this too is changing in order to support a rapidly growing urbanization and poultry industry. Unlike its neighbor, Kenya, which imports a significant share for its consumption needs, Ethiopia has increasingly attained self-sufficiency in maize production since early this decade and even exports some quantities to neighboring countries (e.g., Sudan and Djibouti) in years of surplus production. If production can be significantly expanded, the potential for maize export to all the neighboring countries including Kenya is very high although the national demand is expected to continue to grow in the coming years.

The emerging maize green revolution for Africa that Byerlee and Eicher (1997); Byerlee and Heisey (1997); Byerlee and Jewell (1997); and Eicher and Kupfuma

\footnotetext{
${ }^{1}$ The contributions of all other cereals have either declined or showed little change; the only exception was wheat, with about $21 \%$ in the 2000 s compared to about $18 \%$ in the 1960s (Demeke 2012).
}

(1997) envisioned in the 1990s has remained elusive so far but is showing strong signs of becoming a reality now in Ethiopia and perhaps in other countries of sub-Saharan Africa (SSA). There is evidence that the increased productivity and production of maize is also having a significant positive impact on poverty reduction (Dercon et al. 2009; Zeng et al. 2013). In this article, we bring together our collective knowledge and experience to bear on Ethiopian agriculture and beyond. We analyze the drivers behind this rapid increase in production and productivity of maize and attempt to draw lessons. These lessons and insights are drawn from a review of recent literature, analysis of existing data and from our own long-standing field experience in observing the process of change and productivity growth in Ethiopian agriculture.

\section{Methods}

The major source of production and agricultural input data was the time series publications of the Central Statistical Agency (CSA) (www.csa.gov.et); organized and comprehensive data on inputs are available starting 2004, even though records on production have been going on for a much longer period. We also used unpublished data from the Agricultural Inputs Marketing Directorate of the Ministry of Agriculture (MOA). References in this study have also been made to published sources (e.g., MOA 1984; Tolossa and Ransom 1993; Nigussie et al. 2002; Worku et al. 2012; FAOSTAT 2015) and secondary sources to describe the development of maize that could have significant implications for the future direction of agricultural research and development in Africa.

Furthermore, meteorological data for sites, including Gonder (1973 m asl ${ }^{2} ; 1099 \mathrm{~mm}$ rainfall), Finote Selam $(1980 \mathrm{~m}$ asl; $1300 \mathrm{~mm})$, Bako (1700 m asl; $1316 \mathrm{~mm})$, Jimma (1750 m asl; $1564 \mathrm{~mm}$ ), Wolaita-Sodo (1854 m asl; $1275 \mathrm{~mm}$ ), Hawassa (1980 m asl; $941 \mathrm{~mm})$, Chiro [formerly Asebe-Teferi] (1792 m asl; $767 \mathrm{~mm}$ ), and Haramaya (1900 m asl; $748 \mathrm{~mm}$ ), which represent the major maize production zones in Ethiopia were obtained from the National Meteorological Agency (www.ethiomet.gov.et).

The various data sets mentioned above were used to calculate percent area covered by improved maize varieties as well as areas that received inorganic and organic fertilizers in the various administrative regions. As CSA provides mineral fertilizers as di-ammonium phosphate (DAP) and urea in kilograms, we converted these data sets into actual nitrogen $(\mathrm{N})$ and phosphorus $(\mathrm{P})$ nutrients for standardized comparisons. Information on agro-ecological zones was obtained from the Ministry of Agriculture (MOA 2005). Comprehensive long term yield data were sourced from FAOSTAT (http://faostat.

$\overline{2 \text { asl=above }}$ sea level 
Table 1 Major agro-ecological zones for maize in Ethiopia (MOA 2005)

\begin{tabular}{|c|c|c|c|c|}
\hline Agro-ecological zone & Elevation (m) & $\begin{array}{l}\text { Rainfall } \\
(\mathrm{mm})\end{array}$ & $\begin{array}{l}\text { Estimated } \\
\text { area }(\%)\end{array}$ & Administrative regions \\
\hline Moist and semi-moist mid-altitudes & $1700-2000$ & $1000-1200$ & 30 & $\begin{array}{l}\text { Parts of SNNPR, SW and W Oromia;W and NW Amhara; } \\
\text { Ben Shangul-Gumuz (BSG) }\end{array}$ \\
\hline Moist upper mid-altitudes & $2000-2400$ & $>1200$ & 25 & Central highlands; highlands of SNNPR, Amhara and Oromia \\
\hline Dry mid-altitudes & $1000-1600$ & $650-900$ & 20 & $\begin{array}{l}\text { Parts of SNNPR, SW and W Oromia; W and NW Amhara; } \\
\text { parts of BSG }\end{array}$ \\
\hline Moist lower mid-altitudes & $900-1500$ & $900-1200$ & 15 & Pockets of Amhara, Oromia, SNNPR and BSG \\
\hline Moist lowlands & $<900$ & $900-1200$ & 5 & Gambella and parts of BSG \\
\hline Dry lowlands & $<1000$ & $<700$ & 5 & Afar and parts of Oromia and lowlands of Somali \\
\hline
\end{tabular}

Total maize area was 1.52 million ha

fao.org/site/567/default.aspx\#ancor), whereas yield data for 2004 to 2013 were obtained from CSA (www.csa.gov.et).

To calculate the rate of yield gains over the years, the FAO data were regressed on years. The resulting regression coefficient was taken as an annual rate of yield gain. Additionally, regression analyses were conducted to determine the relationship between maize grain yield and $\mathrm{N}$ and $\mathrm{P}$ applications for the major maize growing administrative regions and at the national level, using the CSA data for 2004 to 2013. We also calculated the annual rates of growth using log estimates. The GLM procedure in Statistical Analysis System (SAS 2007) was used to generate Least Square Means of the total annual rainfall recorded from 1990 to 2012 .

\section{The maize story in Ethiopia}

Maize is the second most widely cultivated crop in Ethiopia and is grown under diverse agro-ecologies and socioeconomic conditions typically under rain-fed production. The maize agro-ecologies in Ethiopia can be broadly divided into six major categories (MOA 2005), including Moist and Semi-moist mid-altitudes (1700-2000 m above sea level; 1000-1200 mm rainfall), Moist upper mid-altitudes (2000$2400 \mathrm{~m} ;>1200 \mathrm{~mm}$ ), Dry mid-altitudes (1000-1600 m; 650-900 mm), Moist lower mid-altitudes (900-1500 m; 900-1200 mm), Moist lowlands (<900 m, 900-1200 mm), and Dry lowlands $(<1000 \mathrm{~m},<700 \mathrm{~mm}))$. As presented in Table 1, the moist and semi-moist mid-altitude zones comprise the bulk of the national maize area in Ethiopia. These are mostly located in the SW and W Oromia, W and NW Amhara, parts of the Southern Nations Nationalities and Peoples Region (SNNPR), and Ben Shangul-Gumuz (BSG). Taken together, the Semi-moist and Moist ecologies cover about $75 \%$ of the national maize production area whereas the dry ecologies cover the remaining $25 \%$.

Smallholder farms account for more than $95 \%$ of the total maize area and production in Ethiopia. The farmers use animal traction for land preparation and cultivation; almost all production is rainfed, irrigated areas accounting for only about $1 \%$ of the total.

Smallholders across all 70 administrative units of Ethiopia, which include 59 zones and 11 special weredas ${ }^{3}$ grow maize (Fig. 1). The top five maize producing zones of Ethiopia, according to the 2011 CSA data, are West Gojjam, Jimma, East Welega, West Welega and East Gojjam. Most of these fall into the mid-altitude (1500-2000 $\mathrm{m}$ asl) range.

More than 9 million households, more than for any other crop, grow maize in Ethiopia (CSA, 2011-13 data). The annual rate of growth for the number of households cultivating maize grew at $3.5 \%$ each year between 2004 and 2013, compared to $3.0 \%$ for sorghum, $3.1 \%$ for teff, $2.1 \%$ for wheat, and $1.8 \%$ for barley. At present, as a sub-Saharan country, Ethiopia has the fifth largest area devoted to maize but is second, only to South Africa, in yield and third, after South Africa and Nigeria, in production.

Maize currently occupies about 2 million ha with an average yield of upwards of $3 \mathrm{MT} / \mathrm{ha}$ (Fig. 2). National maize yields have doubled from about $1.50 \mathrm{MT} /$ ha during the early 1990 s to $3.23 \mathrm{MT} / \mathrm{ha}$ in 2013. Analysis of FAO data revealed that a highly significant $(p<0.0001)$ annual yield gain of $68 \mathrm{~kg} / \mathrm{ha}$ was recorded for maize in Ethiopia for the period 1990 to 2013 . Only South Africa exceeded this figure $(119 \mathrm{~kg} /$ $\mathrm{ha} / \mathrm{yr}$ ) in SSA whereas some countries such as Tanzania and Kenya registered negative growth. Ethiopia's figure is superior to Mexico (55 kg/ha/yr), China (55 kg/ha), and India (47 kg/ha/yr). Yield gains grew even faster $(120 \mathrm{~kg} / \mathrm{ha} / \mathrm{yr})$ between 2000 and 2013 .

Despite the pockets of change across Africa, such change at the national level is a significant transformation in a region where a green revolution seemed largely unattainable (Howard and Mungoma 1997; De Groote et al. 2002; Smale et al. 2011; Smale and Olwande 2014). On average, maize area and productivity increased by 4.0 and $6.3 \% \mathrm{pr}$ annum, respectively, during the 10 years between 2004 and 2013 .

\footnotetext{
${ }^{3}$ A wereda (also spelt woreda) is an equivalent of a county or a district
} 
Fig. 1 Distribution of maize production in Ethiopia. Source: based on CSA data for 2011 (www.csa.gov.et)

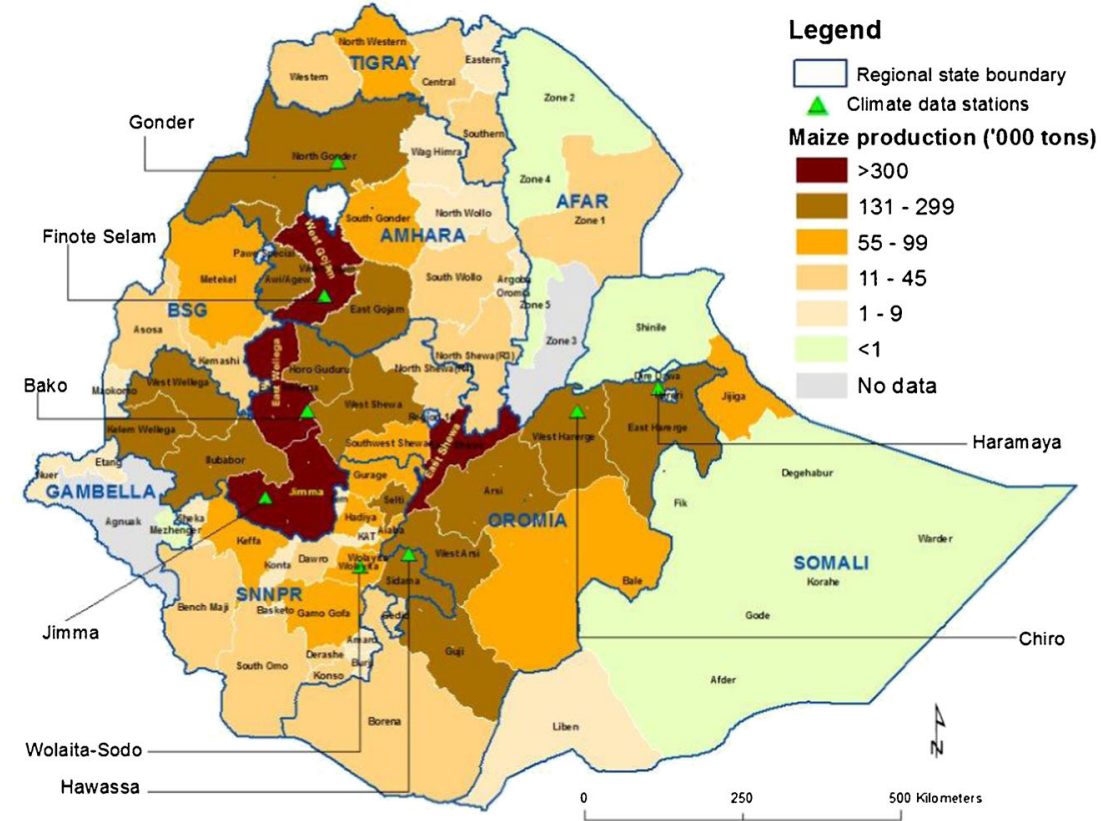

Similarly, the annual rate of growth for production during the same period was $10.5 \%$.

It is interesting to see that the increases in maize production in Ethiopia resulted more from increases in productivity rather than area expansion - i.e., the yield grew faster than the area (Fig. 2). The current performance of maize in Ethiopia compares favorably with the main maize producing countries in SSA (Fig. 3). Ethiopia is the only country in SSA outside South Africa that has attained $>3 \mathrm{MT} / \mathrm{ha}$ yield; only Zambia and Uganda have achieved $>2.5 \mathrm{MT} / \mathrm{ha}$, followed by Malawi, with $>2 \mathrm{MT} / \mathrm{h}$. The SSA average is about $1.8 \mathrm{MT} / \mathrm{ha}$.

Largely because of the increasing demand (Rosegrant et al. 2001) driven by population growth and competitiveness of the crop, maize area in Ethiopia also doubled during the past two decades from 1 to 2 million ha. This increase in area came mainly from two sources. First, the traditionally sorghum-

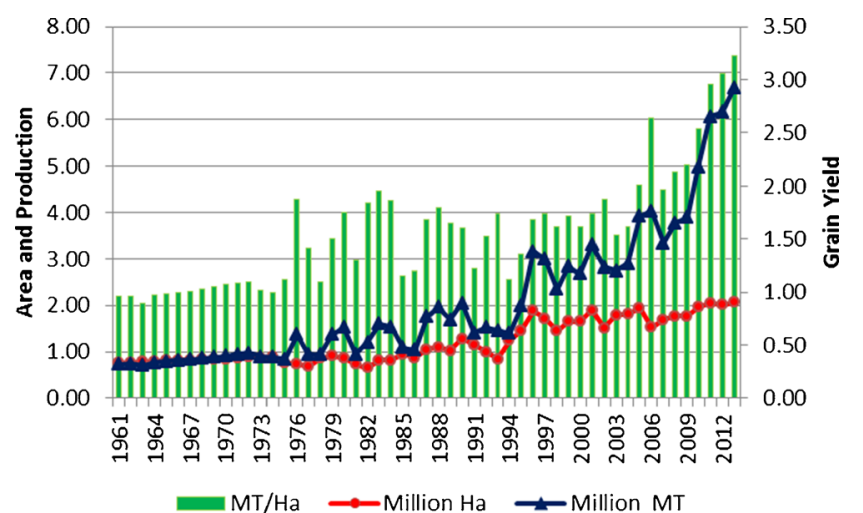

Fig. 2 Performance of maize in Ethiopia, 1961-2013. Source: constructed by the authors from FAOSTAT, accessed on 21/11/2014); the lines (Y1-axis) represent area and production whereas the yield (Y2-axis) is represented by the bars growing smallholder farmers in the rift valley shifted to maize because of the weaver bird (Quelea quelea) invasion that resulted in the total destruction of sorghum in the early 1980s. The second driver of maize area increase was the adoption of maize by the traditional teff-growing farmers in north-central Ethiopia - particularly in West Gojjam, North Gondar, and other surrounding agro-ecologies - because of its high productivity achieved through new hybrids (starting with the hybrid BH140) and diversity in end-uses of maize. Unlike in the central rift valley, farmers here did not necessarily shift from teff to maize but rather expanded the area of the latter.

In general, the growth in the proportion of maize area was higher than all other major cereals over the last three decades (Fig. 4). For example, maize occupied roughly $16 \%$ of the total cereals area in 1981-83 compared to $30 \%$ for teff, $20 \%$ for sorghum, $14 \%$ for wheat, and $19 \%$ for barley; the area occupied by maize, teff, sorghum, wheat and barley in 200103 was $24,31,17,15$, and $13 \%$, respectively. Currently teff, maize, sorghum, wheat and barley occupy $30,22,20,17$, and

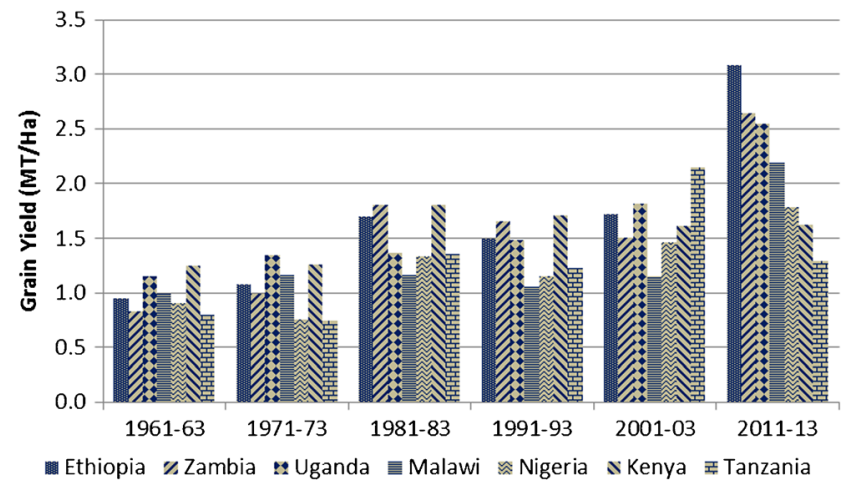

Fig. 3 Maize yield in selected countries of SSA. Source: constructed by the authors from FAOSTAT, accessed on 02/01/2015 


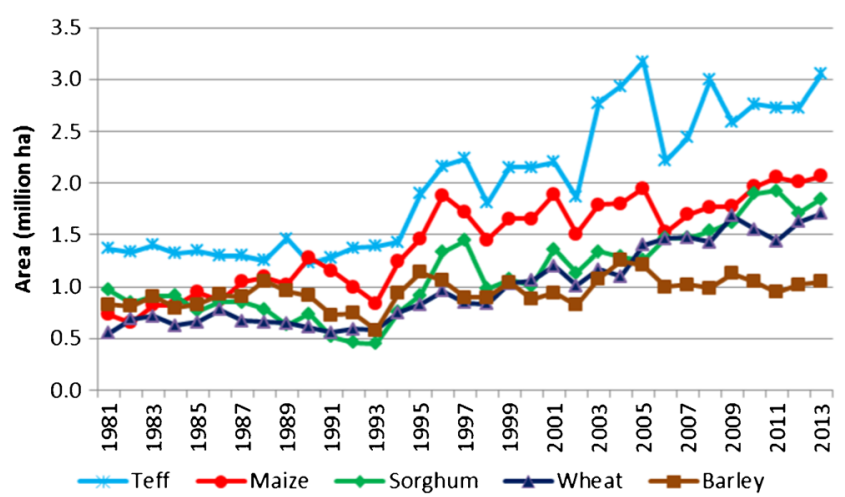

Fig. 4 Area occupied by major cereals in Ethiopia, 1981-2013. Source: constructed by the authors from FAOSTAT, accessed 29/11/2014). Please note that FAOSTAT lumps teff with other cereal data for Ethiopia

$11 \%$, respectively, of the total cereal acreage of Ethiopia. It should be noted here that production of major cereals in Ethiopia remained stagnant in the 1960s and showed dramatic declines in the 1970s and 1980s due to major droughts and political conflicts.

\section{Maize transformation in Ethiopia}

The expansion and productivity change in maize production in Ethiopia is attributable to multiple factors. These include a) increased availability of modern varieties, b) increased commitment to enhance farmer access to and use of modern inputs through better research-extension linkages, c) wider adaptability of the crop and modern varieties, d) better production conditions and low production risks and e) growing consumption demand and market access for producers to support marketbased production to absorb surplus supply. We discuss some of these factors and draw lessons on the key drivers of change in the following section to show the relevance of similar processes of transformation in African agriculture.

\section{Maize research and development}

Maize research and development in Ethiopia has gone through a number of changes over the last several decades, which marked critical periods in terms of driving the current change in production and productivity. We summarize the major ones in Table 2 below. Some of the key events that warrant specific mention include the 1984 major drought and famine that helped to increase the profile of maize in attaining national food security; the introduction of nationally developed hybrids adapted to the local production conditions in the late 1980s and early 1990s; the launching in 1993 of the government campaign, NEIP (National Extension Intervention Program) in partnership with Sasakawa Global 2000 (or SG2000) to increase food security; the introduction of a maize grain floor price in the early 2000s; the introduction of an integrated systems approach for research and development by the Ethiopian Institute of Agricultural Research (EIAR) in the early 2000s (Abate 2006, 2007); and inclusion of maize in the commodity exchange in recent years. Earlier attempts made to introduce hybrids from Kenya were unsuccessful due to poor adaptation to the prevalent production systems and high seed price. Further details can be found in Table 2.

\section{Modern varieties (MVs)}

Undoubtedly, the maize story in Ethiopia is largely homegrown and improved maize germplasm has played a key part in catalyzing change in production practices by replacing traditional varieties with input-responsive, stable and high yielding MVs. The Ethiopian NARS has released a total of 61 maize varieties between 1973 and 2013. The first locally developed hybrid (BH140, in the early- to intermediate-maturity group) was released in 1988, followed by a late- maturing hybrid (BH660) in 1993, and BH540 and the Pioneer Hi-bred Seed Ethiopia hybrid PHB3253 (marketed as Jabi) in 1995.

There was a total of 16 hybrids and 4 Open Pollinated Varieties (OPVs) under production in 2013 (Table 3). Hybrids accounted for $97 \%$ while OPVs represented only $3 \%$ of the total seed market. Furthermore, the Ethiopian seed market has been dominated by BH660 and BH540; the average age of $80 \%$ of the currently grown varieties is more than 20 years. There are also hybrids that came into production between 2005 and 2008, but their amounts remain limited, with the exception of the Pioneer hybrids Shone and Agar (Table 3).

BH661, promoted under the auspices of the Drought Tolerant Maize for Africa (DTMA) project, is of particular significance because of its drought tolerance, resistance to major diseases, higher yield potential and wide adaptability. This variety is expected to replace both BH660 and BH540. The demand for foundation seed by seed companies of this new hybrid is rapidly growing. In 2012 Ethiopian Seed Enterprise (ESE) produced 6 MT of certified seed; by 2014 five companies, including Amhara Seed Enterprise (ASE), Avallo, ESE, Oromia Seed Enterprise (OSE), and Southern Seed Enterprise (SSE) produced nearly 2,900 MT.

Only four OPVs are at all common but their use is limited to the more drought-prone areas such as the central rift valley. The OPVs Melkassa2 and Melkassa4 have been used extensively in the last several years; two new ones (Melkassa6 and Gibe2) were recently introduced into the market and their use is expected to expand before getting replaced by higher yielding hybrids that are in the process of development.

\section{Uptake and diffusion of modern inputs}

Maize inputs in Ethiopia include mainly improved seed and fertilizers. The use of pesticides (including fungicides, 
Table 2 Milestones in maize research and development in Ethiopia

\begin{tabular}{|c|c|c|}
\hline Year & Event & Outcome/Consequences \\
\hline 1966 & $\begin{array}{l}\text { Establishment of EIAR (Apex body for } \\
\text { National Agricultural Research) }\end{array}$ & $\begin{array}{l}\text { Nationally coordinated, agro-ecological zone-based } \\
\text { research launched; accelerated training of researchers; } \\
\text { regional and international collaboration in AR\&D initiated }\end{array}$ \\
\hline 1973 & $\begin{array}{l}\text { First releases of two improved varieties } \\
\text { (A-511 and Alemaya Composite) }\end{array}$ & $\begin{array}{l}\text { Farmers exposed to new, improved maize varieties } \\
\text { (this was followed by an early maturing variety - } \\
\text { Katumani - that remained popular until recent years) }\end{array}$ \\
\hline 1974 & $\begin{array}{l}\text { Major drought and famine } \\
\text { (mainly northern Ethiopia) }\end{array}$ & $\begin{array}{l}\text { Increased demand for food; massive food-aid inflow from } \\
\text { abroad; the famine was the major rallying point by } \\
\text { the military to overthrow Emperor Haileselassie }\end{array}$ \\
\hline 1976 & $\begin{array}{l}\text { Introduction of maize research for moisture } \\
\text { stress (at Awassa College, southern Ethiopia) }\end{array}$ & $\begin{array}{l}\text { Expansion of maize in lower rainfall areas } \\
\text { (e.g., central rift valley) }\end{array}$ \\
\hline 1979 & $\begin{array}{l}\text { Establishment of ESE (Ethiopian } \\
\text { Seed Enterprise) }\end{array}$ & $\begin{array}{l}\text { Enhanced availability of improved/clean seed; savings } \\
\text { on imported seed }\end{array}$ \\
\hline 1980 & $\begin{array}{l}\text { Establishment of multidisciplinary } \\
\text { maize research team }\end{array}$ & $\begin{array}{l}\text { Centers of excellence identified; more research } \\
\text { centers built; international experts recruited } \\
\text { through IDA loan; enhanced understanding } \\
\text { of constraints }\end{array}$ \\
\hline 1982 & Introduction of joint research and extension sites & $\begin{array}{l}\text { Trials conducted under farmers' conditions; enhanced } \\
\text { adoption of improved technologies }\end{array}$ \\
\hline 1984 & Another major drought strikes & $\begin{array}{l}\text { Tarnished image and wounded national pride; search } \\
\text { for solutions and strategies; maize receives high priority }\end{array}$ \\
\hline 1985 & $\begin{array}{l}\text { Official start of National Variety Release } \\
\text { Committee }\end{array}$ & $\begin{array}{l}\text { Criteria for desirable traits and quality standards } \\
\text { established; national commercial variety registry issued }\end{array}$ \\
\hline 1988 & $\begin{array}{l}\text { First release of a locally developed } \\
\text { hybrid (BH140) }\end{array}$ & $\begin{array}{l}\text { Increased potential to improve productivity } \\
\text { (in mid- and lower altitudes) }\end{array}$ \\
\hline 1993 & $\begin{array}{l}\text { Release of BH660 (most productive and } \\
\text { popular hybrid even at present }\end{array}$ & $\begin{array}{l}\text { Increased interest in maize adoption and production in } \\
\text { the traditional growing areas with adequate rainfall; } \\
\text { increased appreciation of for research by policy makers }\end{array}$ \\
\hline 1993 & $\begin{array}{l}\text { Government campaign for increased food } \\
\text { production (in collaboration with Sasakawa } \\
\text { Global 2000) }\end{array}$ & $\begin{array}{l}\text { Increased demand for mineral fertilizer and improved } \\
\text { seed; increased demand for extension }\end{array}$ \\
\hline 1995 & Release of the hybrid BH540 & $\begin{array}{l}\text { Suitable variety for intermediate altitudes made } \\
\text { available; expansion of maize production in } \\
\text { non-traditional areas }\end{array}$ \\
\hline 1995 & $\begin{array}{r}\text { First private release by Pioneer } \\
\text { of a hybrid, Jabi (PHB3253) }\end{array}$ & $\begin{array}{l}\text { Increased availability of improved variety seed; } \\
\text { more options for farmers }\end{array}$ \\
\hline 1995 & $\begin{array}{l}\text { Launching of NEIP (National Extension } \\
\text { Intervention Program) using what is } \\
\text { known as PADETS (Participatory Demonstration } \\
\text { and Extension Training System) approach }\end{array}$ & $\begin{array}{l}\text { Improved coverage of extension services; increased } \\
\text { demand for extension personnel }\end{array}$ \\
\hline 1996 & $\begin{array}{l}\text { ARTP (Agricultural Research and Training } \\
\text { Program) launched }\end{array}$ & $\begin{array}{l}\text { Increased research capacity; increased training and } \\
\text { deployment of extension staff }\end{array}$ \\
\hline 2001 & Maize prices plummet & $\begin{array}{l}\text { Doubts whether farmers would be still interested in } \\
\text { maize production in light of market failure }\end{array}$ \\
\hline 2002 & Government fixes floor price for maize & Improved confidence in maize production \\
\hline 2004 & $\begin{array}{l}\text { EIAR leads the so-called "Ejj-Le-Ejj } \\
\text { (hand-in-hand) campaign }\end{array}$ & $\begin{array}{l}\text { Partnership among AR\&D stakeholders strengthened; } \\
\text { promotion and scaling up/out available technologies } \\
\text { intensified; adoption of improved technologies enhanced }\end{array}$ \\
\hline 2007 & $\begin{array}{l}\text { Partnerships with Drought Tolerant Maize } \\
\text { for Africa (DTMA) and the Program for } \\
\text { Africa's Seed Systems (PASS) projects } \\
\text { launched }\end{array}$ & $\begin{array}{l}\text { Drought and other stress tolerant varieties made available } \\
\text { to smallholder farmers; frequency of variety releases } \\
\text { and commercialization enhanced; increased involvement } \\
\text { of private sector in seed production; increased availability } \\
\text { of improved maize seed }\end{array}$ \\
\hline 2012 & Maize traded on ECX (Ethiopian Commodity Exchange) & Farmers benefit from improved market \\
\hline
\end{tabular}


Table 3 Maize hybrids and Open Pollinated Varieties (OPVs) on the seed market and their relative importance in Ethiopia (as at December 2013)

\begin{tabular}{|c|c|c|c|c|c|}
\hline Release name & Variety name & Release year & Age (years) & Owner & $\begin{array}{l}\text { Percent of total seed } \\
\text { production }\end{array}$ \\
\hline \multicolumn{6}{|l|}{ Hybrids } \\
\hline Limu & P3812W & 2012 & 1 & Pioneer & 0.67 \\
\hline Shala & P2859W & 2011 & 2 & Pioneer & 0.24 \\
\hline BH661 & BH661 & 2011 & 2 & EIAR & 0.04 \\
\hline Wabi & AMH760 & 2011 & 2 & EIAR & 0.08 \\
\hline Agar & P30G79 & 2008 & 5 & Pioneer & 1.96 \\
\hline Morka & UCBS1C2 & 2008 & 5 & EIAR & 0.10 \\
\hline BHQPY545 & BHQPY545 & 2008 & 5 & EIAR & 0.05 \\
\hline Wenchi & AMH850 & 2008 & 5 & EIAR & 0.02 \\
\hline Shone & P30G19 & 2006 & 7 & Pioneer & 7.67 \\
\hline BH543 & BH543 & 2005 & 8 & EIAR & 5.78 \\
\hline Argane & AMH800 & 2005 & 8 & EIAR & 0.03 \\
\hline BH542 & BH542 & 2002 & 11 & EIAR & 0.16 \\
\hline BH540 & BH540 & 1995 & 18 & EIAR & 21.31 \\
\hline Jabi & PHB3253 & 1995 & 18 & Pioneer & 2.38 \\
\hline BH660 & BH660 & 1993 & 20 & EIAR & 51.40 \\
\hline BH140 & BH140 & 1988 & 25 & EIAR & 5.02 \\
\hline Sub-total & & & & & 96.92 \\
\hline \multicolumn{6}{|l|}{ OPVs } \\
\hline Gibe2 & ZM721 & 2011 & 2 & EIAR & 0.01 \\
\hline Melkassa6 & Pool 15C7 QPM & 2008 & 5 & EIAR & 0.25 \\
\hline Melkassa4 & ECA-EE-36 & 2006 & 7 & EIAR & 1.73 \\
\hline Melkassa2 & ZM521 & 2004 & 9 & EIAR & 1.10 \\
\hline Sub-total & & & & & 3.08 \\
\hline
\end{tabular}

Varieties are from the National Variety Registry of MOA; percentages are calculated by the authors from MOA (unpublished data) herbicides and insecticides) is insignificant and available data are sparse. Therefore, below we only analyze available data on the use of improved seed and fertilizers.

\section{Improved seed}

In order to see the patterns of diffusion across the country, we conducted an analysis of CSA data ${ }^{4}$ on use patterns of improved seed across major maize growing administrative regions of Ethiopia - viz. Amhara, BSG, Oromia, SNNP, and Tigray. Owing to the size of maize area, Oromia, followed by Amhara and SNNP, have the largest amount of improved seed usage. ${ }^{5}$ The share of total MVs used in Oromia region during 2010-12 was $49 \%$ of the total; Amhara and SNNP accounted

\footnotetext{
${ }^{4}$ The CSA data do not include recycled seed.

${ }^{5}$ Oromia, Amhara, and SNNP account for 54, 25, and $14 \%$, respectively, of the total maize production of Ethiopia whereas Tigray and BSG cover about $2 \%$ each.
}

for 33 and $18 \%$, respectively, with BSG and Tigray both receiving $<1 \%$ each. $^{6}$

Table 4 depicts the percent area coverage by MVs in Ethiopia between 2004 and 2013. The area covered by MVs varied according to regions and years. The Amhara Region has shown consistently higher percentages of coverage through the 10 year period. For example, the area under MVs was $24 \%$ in 2004, compared to $55 \% 10$ years later. This was followed by SNNP and Oromia, in that order. The national average also followed consistent upward trends, especially over the last 5 years. The national average maize area under MVs in 2013 was $40 \%$, compared to $16 \%$ in 2004. This is a far cry from reports in the distant and recent past (MOA 1984; Langyintuo et al. 2011; Spielman et al. 2013). Most recent studies and adoption monitoring surveys of DTMA suggest that the total maize area covered by MVs is more than $65 \%$ (CIMMYT 2014) but these have mostly

\footnotetext{
${ }^{6}$ Unpublished data from MOA.
} 
Table 4 Percent maize area covered by modern varieties in selected administrative regions of Ethiopia (2004-13)

\begin{tabular}{lllllllllll}
\hline Region & 2004 & 2005 & 2006 & 2007 & 2008 & 2009 & 2010 & 2011 & 2012 & 2013 \\
\hline Amhara & 24 & 26 & 29 & 37 & 35 & 35 & 45 & 50 & 47 & 55 \\
SNNP & 17 & 23 & 10 & 17 & 20 & 18 & 25 & 33 & 32 & 43 \\
Oromia & 15 & 19 & 14 & 15 & 16 & - & 25 & 25 & 33 & 38 \\
BSG & 3 & 8 & 0 & 6 & 8 & - & 8 & 14 & 10 & 17 \\
Tigray & 1 & 2 & 0 & 0 & 1 & - & 1 & 1 & 2 & 3 \\
Ethiopia & 14 & 20 & 15 & 20 & 20 & 23 & 29 & 33 & 34 & 40 \\
Million ha & 1.39 & 1.52 & 1.69 & 1.77 & 1.77 & 1.77 & 1.96 & 2.05 & 2.01 & 2.00 \\
\hline
\end{tabular}

Constructed by the authors from CSA (www.csa.gov.et)

Data for Oromia, BSG and Tigray were inconsistent and left out of the calculation; the national figure is a weighted average of Amhara and SNNP

Total area of maize for the year sampled only limited households in the central rift valley and cannot reflect the national picture.

The federal government-owned company ESE has been the largest supplier of foundation and certified seed in the country until recently. Regional government-owned companies, including the ASE, OSE, and SSE have also entered the seed market in recent years.

The role of the private sector has been limited in the past and private seed companies have been affected by limited technical capacity, lack of land and capital, inadequate access to breeder seed of publicly-bred varieties, less competitive seed pricing, and lack of clarity on freely marketing their materials (Alemu 2010; Alemu et al. 2010; Spielman et al. 2013).

Pioneer Hi-Bred Seed (Ethiopia) ${ }^{7}$ has been an important supplier of hybrid seed since the mid-1990s; its annual average market share between 2004 and 2013 was $21.1 \%$. National small seed companies and community-based organizations (CBOs) such as Meki-Batu Union (MBU) have also entered the maize seed market in recent years. The combined seed market share of parastatals (ESE, ASE, OSE, and SSE) in 2014 was $63 \%$, compared to $31 \%$ for Pioneer Hi-Bred Seed (Ethiopia), $4 \%$ for CBOs, and $2 \%$ for all national small seed companies combined. MBU is the only $\mathrm{CBO}$ marketing maize seed in Ethiopia. Small national seed companies marketing improved maize are represented by Avallo, Ano AgroIndustry, Gadisa Gobena Farm, Hadia, and Ethio VegFru. The southern Africa-based regional seed company, SeedCo, has recently started marketing the maize variety Duma (SC 403) through its local representation by Alemayehu Makonnen Farm. Two new seed companies from India Advanta Seeds and CP Seeds registered new maize varieties in 2013 but have not started marketing them.

\footnotetext{
${ }^{7}$ It should be noted that this company does not have a breeding program in Ethiopia; they test existing hybrids bred in southern Africa and release the best.
}

\section{Fertilizer use}

Historically, Ethiopian farmers have used organic fertilizers (such as farmyard manure, compost, crop residue, and household refuse) for agricultural production. Today, commercial fertilizer use is the dominant input that goes with modern varieties. All of Ethiopia's mineral fertilizer is imported. Based on CSA data for 2004 to 2013, we estimated that about $23 \%$ of the total mineral fertilizer in Ethiopia is applied to maize. Mineral fertilizers in Ethiopia are marketed as DAP (di-ammonium-phosphate) and urea. Potassium fertilizers are not considered to be important in Ethiopian agriculture, as there is a perception that Ethiopian soils are not deficient in this element. Historical data show that, on average, DAP accounts for about $64 \%$ of the total volume of fertilizer used, with urea accounting for the remaining $36 \%$. We converted the two products into $\mathrm{N}$ and $\mathrm{P}$ equivalents and report here the total $\mathrm{N}$ and $\mathrm{P}$ consumption, the area fertilized and application rates.

Figure 5 shows the overall $\mathrm{N}$ and $\mathrm{P}$ consumption by maize in Ethiopia between 2004 and 2013. The total nutrient

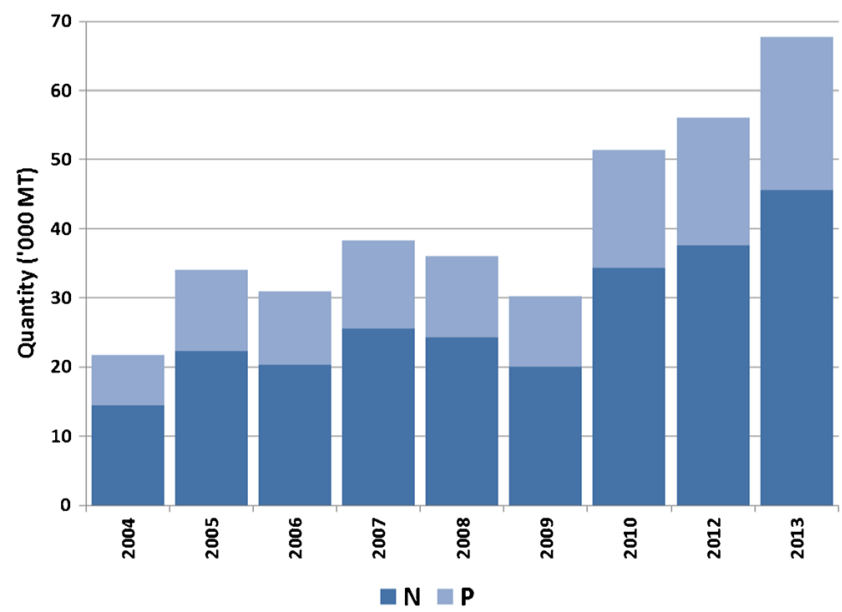

Fig. $5 \mathrm{~N}$ and $\mathrm{P}$ consumption by maize in Ethiopia. Source: Constructed by the authors from CSA data (www.csa.gov.et). Data for 2011 were incomplete and discarded 
Table 5 Percent maize area covered by $\mathrm{N}$ and $\mathrm{P}$ fertilizers in selected administrative regions of Ethiopia

\begin{tabular}{lllllllllll}
\hline Region & 2004 & 2005 & 2006 & 2007 & 2008 & 2009 & 2010 & 2011 & 2012 & 2013 \\
\hline Tigray & 88 & 80 & 78 & 78 & 82 & 83 & 88 & 89 & 89 & 92 \\
Amhara & 84 & 81 & 83 & 82 & 82 & 83 & 86 & 87 & 90 & 85 \\
Oromia & 49 & 53 & 51 & 50 & 50 & - & 59 & 59 & 66 & 67 \\
SNNP & 48 & 53 & 45 & 49 & 49 & 49 & 54 & 64 & 54 & 61 \\
BSG & 36 & 44 & 42 & 41 & 39 & 33 & 41 & 38 & 42 & 41 \\
Ethiopia & 56 & 59 & 57 & 56 & 57 & 62 & 65 & 66 & 68 & 69 \\
\hline
\end{tabular}

Constructed by the authors from CSA (www.csa.gov.et)

Data for Oromia were inconsistent and left out consumption on maize in 2013 was 68,000 MT compared to 20,000 MT in 2004 - a more than 3-fold increase. In other words, fertilizer consumption increased at an annual rate of about $12 \%$ over the 10 years. Overall, $\mathrm{N}$ and $\mathrm{P}$ accounted for approximately 67 and $33 \%$ of this, respectively.

Oromia and Amhara accounted for $43 \%$ each of the total nutrient consumption, with SNNP, Tigray and BSG receiving about 11,2 and $1 \%$, respectively, of the total fertilizer in 2013.

Table 5 depicts the average maize area covered by mineral fertilizers in different regions of the country between 2004 and 2013. An average of $69 \%$ of all maize grown in 2013 in Ethiopia received some amount of mineral fertilizer application, compared to $56 \%$ in 2004 . There were appreciable differences in the maize area receiving fertilizer application among the regions. For example, about $92 \%$ of the area planted to maize in Tigray and $85 \%$ in Amhara received fertilizer in 2013 whereas Oromia, SNNP, and BSG showed lesser area coverage of 67,61 , and $41 \%$, respectively. In other words, the fastest growth in the area covered by mineral fertilizers was in Oromia (with an annual growth rate of $3.0 \%$ ), followed by SNNP (2.6\%) and Tigray (1.3\%); annual growth rates in the maize area covered by fertilizer for Amhara $(0.7 \%)$, and BSG $(0.1 \%)$ were less appreciable. The overall annual growth rate for Ethiopia was $2.3 \%$. The relatively lesser growth rate in area coverage for Amhara is because it was already high even in 2004 (Table 5).

Application rates showed appreciable differences across regions and years both for the overall national average as well as for those who do apply fertilizers (Table 6). The overall application rates more than doubled for all administrative regions and the country as a whole between 2004 and 2013; application rates for those who do apply fertilizers changed little over the course of the 10 years, perhaps with the exceptions of Amhara and SNNP. These two regions showed the fastest annual rates of growth of application rates both for the national average (and those who do use fertilizers) of $8.7 \%$ (4.5\%) and $9.7 \%(4.2 \%)$, respectively.

The national average for all growers is $34 \mathrm{~kg} / \mathrm{ha}$ of $\mathrm{N}$ and $\mathrm{P}$ nutrients. This falls short of the NEPAD recommendation of 2006 (also known as Abuja Declaration) that suggested $50 \mathrm{~kg} /$ ha (Wanzala 2011). Obviously, the national application rate of $68 \mathrm{~kg} / \mathrm{ha}$ in 2013 by those who use fertilizers (and throughout
Table 6 Application rates $(\mathrm{kg} /$ ha) of $\mathrm{N}$ and $\mathrm{P}$ nutrients on maize in selected administrative regions of Ethiopia

\begin{tabular}{|c|c|c|c|c|c|c|c|c|c|}
\hline Region & 2004 & 2005 & 2006 & 2007 & 2008 & 2009 & 2010 & 2012 & 2013 \\
\hline \multicolumn{10}{|c|}{ A: Overall maize growers } \\
\hline Amhara & 26 & 35 & 31 & 43 & 41 & 50 & 48 & 47 & 57 \\
\hline Oromia & 14 & 21 & 17 & 16 & 15 & - & 20 & 25 & 29 \\
\hline SNNP & 11 & 17 & 13 & 21 & 18 & 19 & 24 & 21 & 28 \\
\hline Tigray & 5 & 0 & 5 & 6 & 4 & 7 & 9 & 19 & 19 \\
\hline BSG & 5 & 12 & 9 & 10 & 7 & 8 & 10 & 14 & 13 \\
\hline Ethiopia & 16 & 22 & 18 & 22 & 20 & - & 26 & 28 & 34 \\
\hline \multicolumn{10}{|c|}{ B: Exclusively those applying fertilizers } \\
\hline Amhara & 57 & 70 & 62 & 82 & 83 & 92 & 79 & 74 & 91 \\
\hline Oromia & 58 & 62 & 57 & 61 & 61 & 51 & 52 & 54 & 60 \\
\hline BSG & 49 & 70 & 65 & 69 & 56 & 88 & 62 & 65 & 58 \\
\hline SNNP & 37 & 42 & 40 & 58 & 54 & 56 & 54 & 49 & 53 \\
\hline Tigray & 36 & 0 & 36 & 34 & 28 & 32 & 31 & 45 & 44 \\
\hline Ethiopia & 54 & 62 & 56 & 68 & 68 & 71 & 61 & 59 & 68 \\
\hline
\end{tabular}

Calculated by the authors from CSA (www.csa.gov.et)

Data for 2011 were incomplete and left out 
the 10 years' period) is higher than the NEPAD recommendation. However, both of these still fall short of the national recommendation of about $110-130 \mathrm{~kg} / \mathrm{ha}$ of $\mathrm{N}$ and $\mathrm{P}$ nutrients (or the equivalent of 150-200 kg/ha of urea and $100-150 \mathrm{~kg} /$ ha of DAP), depending on the variety (higher rates are recommended for hybrids). This suggests that, most often, farmers do not always implement the whole package of technologies. The implication of this is that priority for policy makers must be expanding fertilizer use to areas that have not been covered previously, which at present account for more than $30 \%$ of the total maize area in Ethiopia.

We also observed appreciable variation among the regions in the use of organic fertilizers on maize. Application rates were extremely low - averaging about $45 \mathrm{~kg} / \mathrm{ha}$ - and showing little change over the 10 years (not shown in the table). However, there was a persistent decline in the percent area covered by organic fertilizers across the regions and years (Table 7). The national average declined from $27 \%$ in 2004 to $18 \%$ in 2013, an average annual negative growth rate of $2.9 \%$. This has been the case for all regions but some were more seriously affected than others. For example, the annual growth rates for SNNP, Amhara, BSG, and Oromia declined by $6.2,4.9,3.8$, and $1.3 \%$, respectively. Tigray maintained its highest percentage of area under organic fertilizers over the years but the 2013 level was much lower than that in 2004 (Table 7).

The declines in the area covered by organic fertilizers may be attributed to one or both of two things. First, there has been a general decline in the unit area of land available for animal grazing, particularly in the highlands, over the last several decades and therefore associated declines in the number of animals (cattle in particular) kept per family. Second, cow dung is widely used as fuel by farmers or sold as an important source of immediate income. It is also possible that the availability of mineral fertilizers at affordable prices might have also contributed to the decline in the use of organic fertilizer.

To quantify the contribution of the various factors to increases in maize productivity in Ethiopia, we ran regression analyses using grain yield as a dependent variable and each factor as an independent variable (Table 8). We observed significant correlations between maize yield with percent area under MVs, percent area under $\mathrm{N}$ and $\mathrm{P}$ fertilizers, $\mathrm{N}$ and $\mathrm{P}$ application rates for all maize growers, and percent area under organic fertilizer. Correlations between yield and application rate by those using fertilizers were non-significant for Ethiopia and all regions.

There were obvious regional differences for many of the variables tested. For example, area under MVs was significant at $P<0.001$ probability level for Ethiopia, Amhara and SNNP whereas it was significant at $P<0.01$ for Oromia and BSG and non-significant for Tigray. Area under $\mathrm{N}$ and $\mathrm{P}$ fertilizer was highly significant $(P<0.01)$ for Ethiopia and SNNP, significant $(P<0.05)$ for Oromia and Amhara and non-significant both for Tigray and BSG. The overall $\mathrm{N}$ and $\mathrm{P}$ application rate was highly significant for Ethiopia $(P<0.001)$ and Amhara $(P<0.01)$; significant for Oromia, SNNP and BSG $(P<0.05)$, and non-significant for Tigray (Table 8).

There was a highly significant negative correlation between yield and area under organic fertilizer for Amhara $(P<0.001)$, and SNNP and BSG $(P<0.01)$, and significant correlation at the national level $(P<0.05)$. Correlations for Tigray were non-significant (Table 8$)$. Declines in the area covered by organic fertilizers may be a consequence of increases in the availability and use of inorganic fertilizer.

\section{Drivers of change: lessons and insights}

It is perhaps safe to conclude that the major driver of the rapid growth in the production and productivity of maize in Ethiopia is the increased use of MVs, coupled with area covered by $\mathrm{N}$ and $\mathrm{P}$ fertilizer and increased application rate. However, as discussed above, it is also fair to say that there were several other contributing factors to this success. Several of these came together for maize research and development in Ethiopia. In terms of scalability of the process to reach new areas, it is important to identify and draw on those lessons and insights that made this dramatic change in Ethiopia possible. Here we provide highlights of those important enabling conditions.

First, Ethiopia has a well-organized, nationally coordinated agricultural research and development (AR\&D) system with
Table 7 Percent maize area covered by organic fertilizers in selected regions of Ethiopia (2004-13)

\begin{tabular}{lllllllllll}
\hline Region & 2004 & 2005 & 2006 & 2007 & 2008 & 2009 & 2010 & 2011 & 2012 & 2013 \\
\hline Tigray & 74 & - & 65 & 59 & 66 & 60 & 56 & 55 & 46 & 48 \\
Amhara & 37 & 31 & 32 & 29 & 32 & 27 & 24 & 28 & 25 & 20 \\
Oromia & 24 & 19 & 22 & 23 & 25 & 17 & 21 & 23 & 19 & 19 \\
BSG & 26 & 24 & 28 & 26 & 27 & 25 & 24 & 20 & 20 & 18 \\
SNNP & 18 & 13 & 13 & 13 & 16 & 14 & 9 & 11 & 11 & 8 \\
Ethiopia & 27 & 22 & 24 & 24 & 26 & 20 & 21 & 23 & 20 & 18 \\
\hline
\end{tabular}

Constructed by the authors from CSA (www.csa.gov.et) 
Table 8 Regression of maize grain yield on various factors across selected administrative regions of Ethiopia (2004-13)

\begin{tabular}{|c|c|c|c|c|c|c|c|}
\hline \multirow[t]{2}{*}{ Factors } & \multirow[t]{2}{*}{ Parameters } & \multicolumn{6}{|c|}{ Administrative Regions } \\
\hline & & Ethiopia & Oromia & Amhara & SNNP & Tigray & BSG \\
\hline \multirow[t]{2}{*}{ Area under MVs (\%) } & $b$-value & $0.50 * * *$ & $0.40 * *$ & $0.40 * * *$ & $0.49 * * *$ & 1.58 & $0.84 * *$ \\
\hline & $\mathrm{R}^{2}$ & 0.84 & 0.67 & 0.86 & 0.78 & 0.11 & 0.73 \\
\hline \multirow[t]{2}{*}{ Area under NP fertilizer (\%) } & $b$-value & $0.51 * *$ & $0.32 *$ & $1.04 *$ & $0.74 * *$ & 0.51 & 0.20 \\
\hline & $\mathrm{R}^{2}$ & 0.60 & 0.47 & 0.34 & 0.65 & 0.30 & 0.02 \\
\hline \multirow[t]{2}{*}{$\mathrm{NP}$ application rate $(\mathrm{kg} / \mathrm{ha})$ - overall maize growers } & $b$-value & $0.77 * * *$ & $0.56^{*}$ & $0.39 * *$ & $0.79 *$ & 0.47 & $1.05^{*}$ \\
\hline & $\mathrm{R}^{2}$ & 0.09 & 0.06 & 0.13 & 0.27 & 0.22 & 0.01 \\
\hline \multirow[t]{2}{*}{ NP application rate $(\mathrm{kg} / \mathrm{ha})$ - exclusively those applying applying fertilizers } & $b$-value & 0.18 & -0.13 & 0.22 & 0.21 & 0.08 & -0.05 \\
\hline & $\mathrm{R}^{2}$ & -0.09 & -0.12 & 0.23 & -0.04 & -0.08 & -0.13 \\
\hline \multirow[t]{2}{*}{ Area under organic fertilizer $(\%)$} & $b$-value & $-1.31^{*}$ & -0.62 & $-0.86 * * *$ & $-1.56^{* *}$ & -0.05 & $-1.31 * *$ \\
\hline & $\mathrm{R}^{2}$ & 0.52 & 0.10 & 0.81 & 0.73 & 0.06 & 0.73 \\
\hline
\end{tabular}

$*, * *$, and $* * *$ denote significant difference from zero at $p<0.05, p<0.01$ and $p<0.001$ levels, respectively (source: calculated by the authors from CSA www.csa.gov.et)

clearly defined vision and responsibilities. Moreover, Ethiopia's AR\&D system is not dependent on external funding. Government support for research has been consistent throughout the years. Ethiopia's spending on AR\&D grew by 10.9 and $16.5 \%$ per year between 1991 and 96 and 1996 and 2001, respectively; similarly, the number of researchers also grew at 8.7 and $10.3 \%$ during the same period (Beintema 2011). Ethiopia spent $16.5 \%$ of its total expenditure in agriculture in 2005 (Fan and Saurkar, undated). The research system introduced hybrid maize for the first time in the early 1990s. The introduction of hybrid maize came at a very opportune moment when the government was about to launch its program on improved food security and ending extreme poverty. These efforts demonstrated the importance of locally-led innovations and appropriate technologies in igniting the process of a green revolution in Ethiopia.

Second, the Government support and commitment for agricultural extension in Ethiopia. These created farmer awareness ${ }^{8}$ of available technologies and enhanced knowhow in many major growing regions, especially on major and priority staple crops such as maize, wheat, teff, and legumes, which has led to improvement of food security across the country. Whereas public extension systems across SSA have declined significantly over the years, Ethiopia has trained nearly 63,000 young men and women as agricultural extension agents throughout the country starting in the first half of 2000 (Davis et al. 2009). Ethiopia's extension agent to farmer ratio is estimated at 1:476, compared to 1:1000 for Kenya, 1:1603 for Malawi, and 1:2500 for Tanzania (Kassie et al. 2015). This has had a significant effect in creating awareness of the new

${ }^{8}$ The international NGO SG2000 played a significant role in creating awareness by smallholder farmers about improved maize and other major cereals technologies. technologies by smallholder farmers and enhanced adoption, thereby contributing to poverty reduction (Dercon et al. 2009; Dorosh and Thurlow 2013; Spielman et al. 2013; Zeng et al. 2013). Working with 15 villages in Ethiopia, Dercon et al. (2009) reported that receiving at least one extension visit reduces poverty by nearly $10 \%$ and increases consumption by more than $7 \%$.

Third, whereas farmers historically received seasonal input credit for seed and fertilizer through cooperatives and development banks, this has changed significantly over time. Following the structural adjustment and liberalization policies implemented since the early 1990s, there has been no direct input or credit subsidy provided by the government. Given the high input costs for smallholder farmers to benefit from integrated input packages, seasonal credit is important for the relaxation of liquidity constraints. Most of the credit for fertilizer, improved seed and agrochemicals comes from farmer cooperatives, the offices of agriculture and rural development, and the private sector. In 2009, the cooperatives provided about 60,38 and $12.5 \%$ of the credit for fertilizer, improved seed and agrochemicals, respectively (Gebremedhin et al. 2009). The role of development banks as sources of direct credit to farmers has declined significantly.

Fourth, EIAR introduced a paradigm shift in AR\&D in the early 2000s towards an innovation systems approach that is based on active participation of farmers in technology development and diffusion and involvement of partnerships with several actors along the value chain (Abate et al. 2011); agricultural technology scaling was championed by the top leadership and started to show results in terms of enhancing the relevance of research itself and approaches for linking research with smallholders.

Fifth, through proper targeting of the technology, maize varieties were adopted by farmers in north-central and 
northwest Ethiopia where the crop had not been grown traditionally on such a large scale; today these areas are among the most highly productive and largest producers of maize in the country. As new adopters, the farmers in these areas have the advantage of adopting the most modern methods of production - planting in rows, increased use of MVs and fertilizer, and good crop management.

Sixth, increased liberalization and investment in marketing systems, including farmer cooperatives and infrastructure development in rural areas has created opportunities to remedy traditional market failures as farmer coops, agro-dealers, traders and other service providers increasingly connected the remote producing regions into the national economy. A hard lesson was learned at early stages about the importance of market development and commercialization when maize prices collapsed in 2001/02 following a bumper harvest the previous year. In the absence of storage and processing facilities, farmers were forced to sell maize at throwaway prices. This made it abundantly clear that productivity change cannot be sustained without commensurate interventions to improve the marketing systems. The increased liberalization and participation of both the private sector and farmers' cooperatives in grain marketing has reduced the market risks for farmers and fueled the uptake of modern technologies (Bernard and Spielman 2009; Gebremedhin et al. 2009). More recently, maize has also been included along with other crops under the commodity exchange (ECX) system, further reducing the problem of asymmetric information and transaction costs through adoption of harmonized standards and warehouse receipt systems. The overall impact of this on cereal marketing in Ethiopia is yet to be evaluated.

Finally, the human effort has benefited from adequate rainfall and absence of extended drought over the last two decades (Fig. 6) ${ }^{9}$ affecting large production regions similar to those of the mid-1970s and early 1980s. As shown in Fig. 6, the national average annual precipitation varied from 829 to $1352 \mathrm{~mm}$ for 23 years, with differences among years being not statically significant. This has helped the continued growth of maize production and productivity. How this will play out in the future under climate variability and change is uncertain. Farmers will need to adopt sustainable intensification options along with modern inputs to cushion themselves from such shocks (Shiferaw et al. 2014b).

The lessons for policy makers in Ethiopia are obvious maize has demonstrated that productivity change is achievable: indigenous innovation and investment in agriculture are paying dividends and they need to be expanded to large areas which have not yet benefited from these game-changing research products. This requires further strengthening of the

\footnotetext{
${ }^{9}$ Please note that the seasonal average rainfall between 2003 and 2012 was always greater than $800 \mathrm{~mm}$ - adequate for maize production - provided that it is well distributed.
}

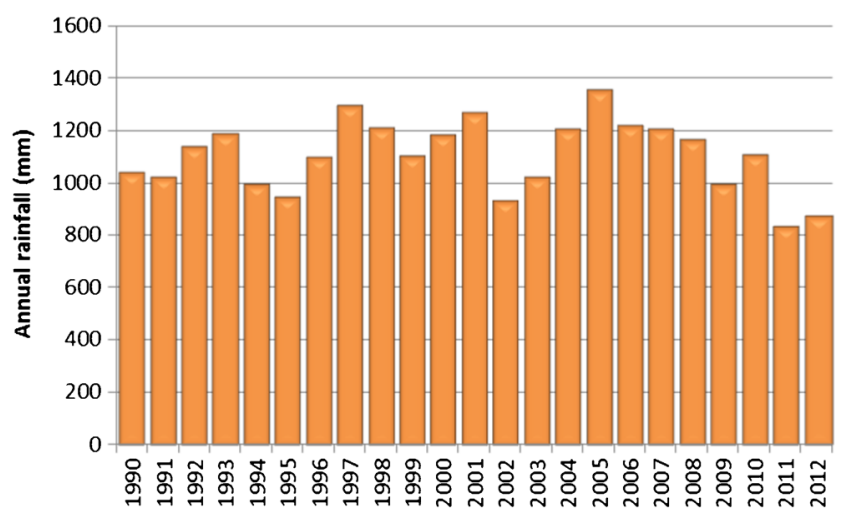

Fig. 6 Average annual rainfall for maize growing areas of Ethiopia (source: constructed by the authors from National Meteorological Agency data; sample station names are shown in Figu. 1)

research, extension and input supply systems through increased investment in generating new products, enhancing the use of home-grown research results, giving recognition to outstanding researchers, retaining experienced researchers and increasing competitiveness in the delivery of quality seed, complementary inputs and services to farmers. The maize story has clearly shown that technology alone will not lead to transformation; farmers will need access to credit, extension and market services to drive and benefit from sustained productivity growth. The lesson for other African countries is the fact that there are no shortcuts to increasing agricultural production and productivity; long-term and sustained investment is the key to achieving that goal, as seen here for maize, and for other crops such as legumes (Abate et al. 2011) and wheat (Shiferaw et al. 2014a; Zeng et al. 2013).

\section{Conclusions and policy implications}

This study has shown that maize area and yields in Ethiopia have doubled since the early 1990s, making it feasible for national yields to reach more than $3 \mathrm{MT} / \mathrm{ha}$ which is significantly higher than the average for SSA. This change and transformation were fueled through indigenous innovation processes ranging from development of widely adapted and profitable varieties and hybrids, increased investment in public extension systems, seed and fertilizer supply and improved access to markets for smallholder producers in the outlying areas. This has clearly shown that maize can be a model for scaling agricultural innovations to achieve locally driven transformation to greatly improved productivity.

Despite the significant changes, there are unexploited opportunities for further increasing maize productivity and production in Ethiopia. Most importantly, a significant portion of the maize area is yet to be reached with modern innovations and several new hybrids are yet to be integrated into the seed production and extension systems. Exploiting these potentials will require replacing the old varieties such as BH140, BH660 
and BH540, which are still dominating the seed system; increased participation of private seed companies in the production and marketing of both foundation and certified seed; expanding the use of improved varieties; and increasing both the application rate and the share of area under mineral fertilizers. These will require addressing some of the remaining handicaps that reduce farmer access to modern varieties, inputs and services. Some of the institutional and policy issues raised by several authors, especially around the seed system (e.g., Alemu 2010; Alemu et al. 2010; Dorosh and Rashid 2013; Rashid et al. 2013; Spielman et al. 2013), have been changing, albeit slowly, through partnerships with the national program and regional initiatives such as DTMA, Program for Africa's Seed Systems (PASS), and other bilateral programs. We highlight below some of the key issues, including the need for variety replacement, addressing issues related to seed systems, raising the level of input use, and maintaining a critical mass of researchers.

The first issue is increased transformation and modernization of the extension system. The public sector extension programs currently coordinate the provision of credit and the supply of inputs, including seed, fertilizer and credit. Part of this service needs to be privatized (including farmers' co-ops) so that extension workers can focus on farmer education and innovation. The conventional top-down and supply-driven approaches for extension still remain across the country and this needs to quickly give way to provision of efficient services in terms of information, knowledge, and skills, and facilitation of linkages with other institutional support services of input supply, credit service, and output marketing (Gebremedhin et al. 2009). In a competitive environment, farmers' cooperatives can play a greater role in enhancing farmer access to local public goods (extension, market information) and services (credit and rural finance), especially when there are no alternative providers (e.g., remote villages).

The Ethiopian farmer cannot rely on varieties that are, or close to, 20 years old, mainly BH660 and BH540, which accounted for nearly $73 \%$ of seed produced of all varieties in the country in 2013. There are reports that these hybrids are deteriorating in their reaction to diseases and their yield performance. BH140 was released more than 25 years ago and was still in use in 2013. Proven technologies with high adaptability and productivity potential need to reach farmers both to enhance competitiveness and build resilience in the face of climatic and market-induced shocks.

There are a good number of new hybrids and a couple of OPVs released within the last 5 years (Table 2) and entering the seed system, but their seed production and use needs to be accelerated. Emphasis should be put on the promotion and inclusion of high-yielding and low-risk varieties that have been released more recently (e.g., BH661, MH130, MH138Q, MH140, BH546, BH547, and Gibe-2).
Initiatives are being undertaken by MOA to implement the "direct seed marketing" 10 - i.e., private seed companies can sell their seed to farmers directly even beyond their immediate vicinities but there is a strong need for a more inclusive approach; the role of the private sector is crucial to making this approach more effective. Increased access to modern inputs through improved seed systems and better access to credit and markets will reduce seed recycling and encourage farmers to invest in fresh and high quality seed. Recycling of seed (including maize hybrids) is a common problem, partly because of credit and capital constraints, and partly due to inadequate supply of modern varieties.

One major factor limiting increased production and use of improved seed in Ethiopia is the inadequate quantity and quality of foundation seed (FS). Currently, the public sector, more specifically, the research centers at Bako and Melkassa and ESE are responsible for FS production. Mechanisms need to be established to help expand FS production by the private sector. The private sector should be encouraged and supported to include FS production into their seed business portfolio.

As stated earlier, the overall fertilizer application on maize in Ethiopia has shown significant growth over the last decade. The consumption rate grew at more than $12 \%$ per annum between 2004 and 2013, in comparison to the SSA average of $3.8 \%$ (between 2004 and 2012). Ethiopia has one of the fastest growth rates of fertilizer usage in SSA. However, the country needs to make every effort towards achieving the Abuja Declaration of $50 \mathrm{~kg} / \mathrm{ha}$ fertilizer use - from its current figure of about $34 \mathrm{~kg} / \mathrm{ha}$. The declining trend of organic fertilizer application on maize should be of concern to researchers and policy makers alike; there is urgent need to find mechanisms to reverse the current condition (e.g., through rotations and intercropping with legumes and manure application).

Finally, although it has taken substantial time and more needs to be done yet, the recent trends in maize productivity and diffusion of modern inputs clearly indicate that Ethiopia is now on track to consummate the full potential for productivity change and green revolution. As popular as it is, maize certainly offers these possibilities for dramatic improvement in food security and can become an example for other crops to emulate. The homegrown research, institutional support and sustained commitment to agricultural research and development are the key drivers of this change. Hence, it is essential to progressively improve access to and effectiveness of extension and marketing services and continue to increase the critical mass of researchers and retain highly skilled and qualified scientists by providing appropriate incentives if further advances are going to be made in improving the productivity of maize and other crops in a sustainable manner.

\footnotetext{
${ }^{10}$ Past regulations restricted seed sales by private companies to government designated areas or parastatals.
} 
The rapid growth in population and urbanization will increase the demand for more food as well as for industrial and other uses of maize in Ethiopia. Consequently, maize will remain a strategic crop to meet this demand in the foreseeable future. The rapid emergence of new indigenous seed companies, coupled with the continued generation of a large number of productive hybrids adapted to the diverse production systems and socio-economic circumstances will enhance competitiveness of the seed system, which in turn will further contribute to sustained maize productivity gains in Ethiopia.

Acknowledgments We are grateful to Drs. Greg Edmeades (formerly CIMMYT Maize Director), Steve Franzel (Senior Economist at ICRAF) and David Bergvinson (Director General of ICRISAT) for their critical reviews of the earlier version of the manuscript. We would like to thank Drs. Gary Atlin and Tony Cavalieri - both of the Bill and Melinda Gates Foundation (B\&MGF) for challenging the senior author to write this paper and giving useful comments on the earlier draft. Dr. Derek Byerlee (formerly of the World Bank) gave us comments on the "big picture" aspect of this paper. Drs. David Spielman and Shahidur Rashid (both of IFPRI) provided useful reference materials and suggestions. We also acknowledge useful comments and suggestions by Drs. Mulugetta Mekuria and Mosisa Worku (both of CIMMYT). We highly appreciate the critical reviews of three anonymous reviewers on another older version of the manuscript, and substantial editorial assistance and scrutiny by Dr. Richard Strange, editor of this journal. This study was sponsored by the DTMA project, funded by the B\&MGF.

Open Access This article is distributed under the terms of the Creative Commons Attribution 4.0 International License (http:// creativecommons.org/licenses/by/4.0/), which permits unrestricted use, distribution, and reproduction in any medium, provided you give appropriate credit to the original author(s) and the source, provide a link to the Creative Commons license, and indicate if changes were made.

\section{References}

Abate, T. (2006). Successes with value chain: Proceedings of the international conference on scaling up and scaling out agricultural technologies in Ethiopia. Ethiopian Institute of Agricultural Research (EIAR): Addis Ababa.

Abate, T. (2007). Focusing agricultural research to address development needs: Direction for agricultural research in Ethiopia. Addis Ababa: EIAR.

Abate, T., Shiferaw, B., Gebeyehu, S., Amsalu, B., Negash, K., Assefa, K., Eshete, M., Aliye, S., \& Hagmann, J. (2011). A systems and partnership approach to agricultural research for development: lessons from Ethiopia. Outlook on Agriculture, 40, 213-220.

Alemu, D. (2010). The political economy of Ethiopian cereal seed systems: State control, market liberalisation and decentralisation, Working Paper 017. Future Agricultures (www.futureagricuultures.org).

Alemu, D., Rashid, S., \& Tripp, R. (2010). Seed system potential in Ethiopia: Constraints and opportunities for enhancing the seed sector (p. 62). Washington DC: IFPRI.

Beintema, N. (2011). A benchmark of agricultural research investment and capacity trends across ASARECA countries. Washington DC: IFPRI.

Berhane, G., Paulos, Z., Tafere, K., \& Tamru, S. (2011). Food grain consumption and calorie intake patterns in Ethiopia. Addis Ababa: IFPRI.
Bernard, T., \& Spielman, D. J. (2009). Reaching rural poor through rural producer organizations? A study of the agricultural marketing cooperatives in Ethiopia. Food Policy, 34, 60-69.

Byerlee, D., \& Eicher, C. K. (1997). Africa's emerging maize revolution. Boulder: Lynne Rienner Publishers.

Byerlee, D., \& Heisey, P. W. (1997). Evolution of the African maize economy. In D. Byerlee \& C. K. Eicher (Eds.), Africa's emerging maize revolution. Boulder: Lynne Rienner Publishers.

Byerlee, D., \& Jewell, D. (1997). The technological foundation of the revolution. In D. Byerlee \& C. K. Eicher (Eds.), Africa's emerging maize revolution. Boulder: Lynne Rienner Publishers.

CIMMYT. (2014). Sustainable agricultural intensification through multitechnology adoption: A regional overview from east and southern Africa. Socioeconomic Program Policy Brief No. 4. Mexico: CIMMYT.

Davis, K., Swanson, B., \& Amudavi, D. (2009). Review and recommendations for strengthening the agricultural extension system in Ethiopia.. Washington, D. C: IFPRI.

De Groote, H., Doss, C., Lyimo, S. D., \& Mwangi. W. (2002). Adoption of maize technologies in East Africa -What happened to Africa's emerging maize revolution? Tokyo: Paper presented at the FASID Forum V, "GREEN Revolution in Asia and its Transferability to Africa", Tokyo, December 8-10, 2002.

Demeke, M. (2012). Analysis of incentives and disincentives for maize in Ethiopia.. Technical notes series, MAFAP. Rome: FAO.

Dercon, S., Gilligan, D. O., Hoddinott, J., \& Woldehanna, T. (2009). The impact of agricultural extension and roads on poverty and consumption growth in fifteen Ethiopian villages. American Journal of Agricultural Economics, 91, 1007-1021.

Dorosh, P., \& Rashid, S. (2013). Food and agricultural policy in Ethiopia: Progress and policy Challenges. Philadelphia: University of Pennsylvania Press.

Dorosh, P., \& Thurlow, J. (2013). Implications of accelerated agricultural growth for household incomes and poverty in Ethiopia: a general equilibrium analysis. In P. Dorosh \& S. Rashid (Eds.), Food and agricultural policy in Ethiopia: Progress and policy challenges. Philadelphia: University of Pennsylvania Press.

Eicher, C. K., \& Kupfuma, B. (1997). Zimbabwe's emerging maize revolution. In D. Byerlee \& C. K. Eicher (Eds.), Africa's emerging maize revolution. Boulder: Lynne Rienner Publishers.

Fan, S., \& Saurkar, A. (undated). Tracking agricultural spending for agricultural growth and poverty reduction in Africa. ReSAKSS (Regional Strategic Analysis and Knowledge Support System), Africa Wide. Washington, D. C: IFPPRI.

FAOSTAT. (2015). Statistical databases and data-sets of the Food and Agriculture Organization of the United Nations. http://faostat.fao. org/default.aspx. Accessed 02 Jan 2015.

Gebremedhin, B., Jaleta, M., \& Hoekstra, D. (2009). Smallholders, institutional services, and commercial transformation in Ethiopia. Agricultural Economics, 40, 773-787.

Howard, J., \& Mungoma. (1997). Zambia's stop-and-go maize revolution. In D. Byerlee \& C. K. Eicher (Eds.), Africa's emerging maize revolution. Boulder: Lynne Rienner Publishers.

Huffnagel, H. P. (1961). Agriculture in Ethiopia. Rome: FAO.

Kassie, M., Teklewolde, H., Jaleta, M., Marenya, P., \& Erenstein, O. (2015). Understanding the adoption of a portfolio of sustainable intensification practices in eastern and southern Africa. Land Use Policy, 42, 400-411.

Langyintuo, A., Mwangi, W., Diallo, A., MacRobert, J., Dixon, J., \& Bänziger, M. (2011). Challenges of the maize seed industry in eastern and southern Africa: a compelling case for private-public intervention to promote growth. Food Policy, 35, 323-331.

McCann, J. C. (2005). Maize and grace: Africa's encounter with a new world crop, 1500-2000. Cambridge: Harvard University Press.

MOA. (1984). General agricultural survey. Preliminary report 1983/84 (1976 EC). Vol. I. Addis Ababa: Ministry of Agriculture. 
MOA. (2005). New agro-ecological zones of Ethiopia. Addis Ababa: Ministry of Agriculture.

Nigussie, M., Tanner, D., \& Twumasi-Afriye, S. (2002). Proceedings of the second national maize workshop of Ethiopia. Addis Ababa: EIAR.

Rashid, S., Tefera, N., \& Ayele, G. (2013). Fertilizer in Ethiopia. An assessment of policies, value chain and profitability. Discussion Paper 01304. Washington, DC: IFPRI.

Rosegrant, M., Paisner, M., Meijer, S., \& Witcover, J. (2001). Global food projections to 2020. 2020 Vision Initiative. Washington, DC: IFPRI.

SAS Institute Inc. (2007). SAS guide for personal computers (9th ed.). Cary: SAS Institute Inc.

Shiferaw, B., Kassie, M., Jaleta, M., \& Yirga, C. (2014a). Adoption of improved wheat varieties and impacts on household food security in Ethiopia. Food Policy, 44, 272-284.

Shiferaw, B., Tesfaye, K., Kassie, M., Abate, T., Prasanna, B. M., \& Menkir, A. (2014b). Managing vulnerability to drought and enhancing livelihood resilience in sub-Saharan Africa: Technological, institutional and policy options. Weather and Climate Extremes, 3, 67-79.

Smale, M., \& Olwande, J. (2014). Demand for maize hybrids and hybrid change on smallholder farms in Kenya. Agricultural Economics, 45, 1 12.

Smale, M., Byerlee, D., \& Jane, T. (2011). Maize revolution in SubSaharan Africa. Policy research working paper 5659, World Bank.

Spielman, D. J., Alemu, D., \& Kelemework, D. (2013). Seeds, fertilizer, and agricultural extension in Ethiopia. In P. Dorosh \& S. Rashid (Eds.), Food and agricultural policies in Ethiopia: Progress and challenges. Philadelphia: University of Pennsylvania Press.

Tolossa, B., \& Ransom, J. K. (1993). Proceedings of the first national maize workshop of Ethiopia. Addis Ababa: EIAR.

Wanzala, M. N. (2011). Seventh progress report January-December 2010 implementation of the Abuja Declaration on fertilizer for an African green revolution. Midrand: NEPAD.

Worku, M., Twumasi-Afriyie, S., Wolde, L., Tadesse, B., Demissie, G., Bogale, G., Wegary, D., \& Prasanna, B. M. (Eds.). (2012). Meeting the challenges of global climate change and food security through innovative maize research, Proceedings of the third national maize workshop of Ethiopia. Addis Ababa: EIAR.

Zeng, D., Alwang, J., Norton, G. W., Shiferaw, B., \& Jaleta, M. (2013). Ex-post impacts of improved maize varieties on poverty in Ethiopia. Washington, DC: IFPRI (Unpublished manuscript).

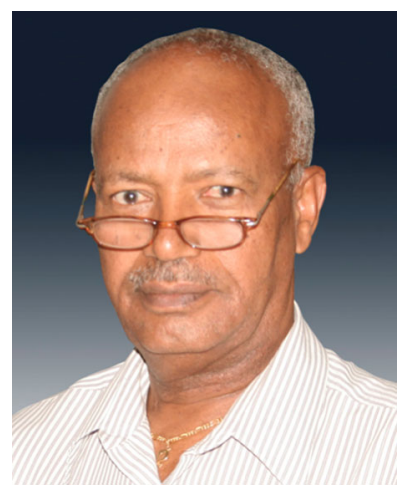

Tsedeke Abate was formerly Director General of the Ethiopian Institute of Agricultural Research (EIAR) and currently leads the Drought Tolerant Maize for Africa project, implemented in 13 countries across Africa, based at CIMMYT-Nairobi. Prior to joining CIMMYT, Tsedeke led the Tropical Legumes II project which was jointly implemented by the International Crops Research Institute for the Semi-Arid Tropics (ICRISAT), the International Center for Tropical Agriculture (CIAT), and the International Institute of Tropical Agriculture (IITA), in Africa and South Asia. Tsedeke is best known for his passion for putting agricultural knowledge into practical use - scaling up and scaling out improved technologies to impact the lives and livelihoods of smallholder farmers. Tsedeke has published widely on African agriculture. He obtained his BS in agriculture (high honors, 1977) from the University of Florida, Gainesville, Florida, USA; MS in entomology/agriculture (1979), also from the University of Florida; and a $\mathrm{PhD}$ in biological sciences (1990) from Simon Fraser University, Vancouver, Canada.

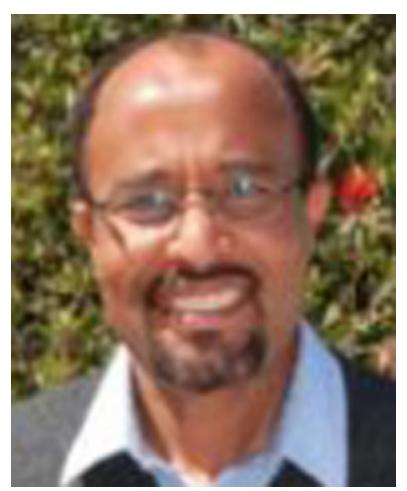

Bekele Shiferaw is currently the Executive Director of the Partnership for Economic Policy (PEP), based in Nairobi, Kenya. He has also served in various capacities in the CGIAR institutions including his most recent role as Director of the Socioeconomics Program at CIMMYT. His research interests span the role of institutions and policies for agricultural development and change; technology adoption; measurement of development and environmental impacts policy interventions; analysis of market relations and commodity value chains; policy and institutional innovations for remedying market failures; and strategies for sustainable intensification and enhancing adaptation to climate variability and change. He has published over 50 papers in peer-reviewed international journals and books. He received his $\mathrm{PhD}$ degree in Development and Resource Economics from the School of Economics and Business, University of Life Sciences, Norway.

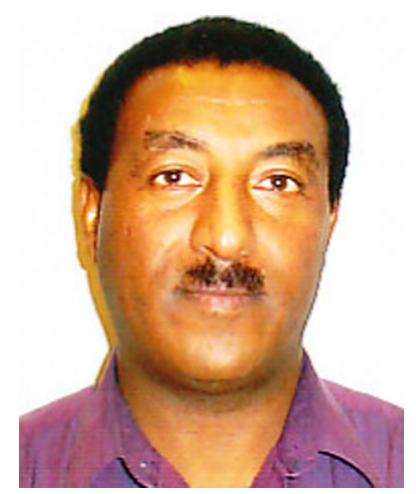

Abebe Menkir was a sorghum and finger millet breeder at the Alemaya College of Agriculture and EIAR in Ethiopia. He has been a maize breeder-geneticist at IITA since 1996 with research emphasis on breeding for high yield potential, resistance to diseases and Striga, drought tolerance, enhanced mineral and provitamin A content. He has been the team leader for maize improvement research at IITA since 2001. Abebe promotes access to improved maize germplasm and enjoys training post-graduate students and partners. He has been involved in the release of several improved maize varieties and hybrids in different countries and advocates the supply of diverse products to farmers through different delivery channels. Abebe received his BSc in Plant Science from Addis Ababa University in Ethiopia, MSc in plant breeding from the University of Manitoba in Canada, and a $\mathrm{PhD}$ in plant breeding from Kansas State University in the USA. 


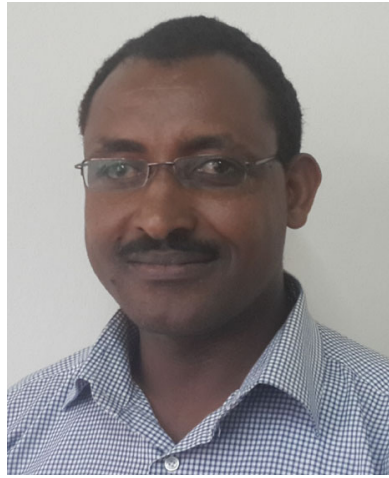

Dagne Wegary is a seed systems specialist for Eastern Africa, based at CIMMYT-Ethiopia. Before joining CIMMYT, he worked as maize breeder and as the National Coordinator of the Maize Research Project at EIAR. He led several Network Projects on maize breeding, technology scaling and seed sector development. His research interests cover maize breeding for stress tolerance, enhanced nutritional quality and high productivity, as well as improving maize seed systems in Africa. He guided the research projects of several MSc and PhD students, and published widely research articles on maize breeding for biotic and abiotic stress tolerance/resistance, and protein quality. Dagne obtained his BSc degree in Plant Sciences (1995) and MSc in Plant Breeding (2002) from Haramaya University, Ethiopia; and $\mathrm{PhD}$ in Plant Breeding (2009) from University of the Free State, Bloemfontein, South Africa.

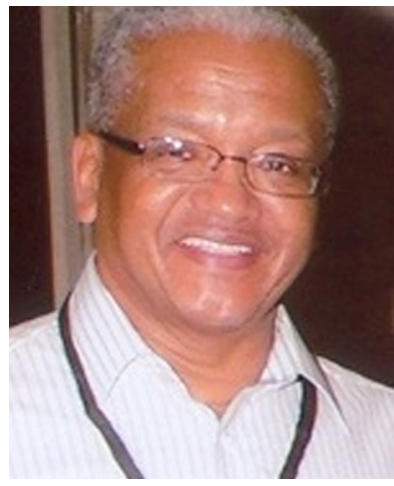

Yilma Kebede serves as a Senior Program Officer in Agricultural Development at the Bill \& Melinda Gates Foundation. Yilma has over 25 years of experience in plant breeding research and germplasm development in public and private sectors. Prior to joining the foundation he was a research coordinator/scientist in the sorghum breeding program with Pioneer Hi-Bred International. He previously served as National Program Leader for sorghum research, and Director, Nazareth Research Center of EIAR. Yilma earned his BSc in Plant Science from the College of Agriculture, Haile Selassie I University (Ethiopia); MSc in Crop Physiology from the University of Guelph (Canada); and a PhD in Plant Breeding and Genetics from Texas A\&M University, USA. Yilma has a long history of service to the greater Eastern Africa agricultural community and was a Fulbright scholar at Purdue in 1990/91.

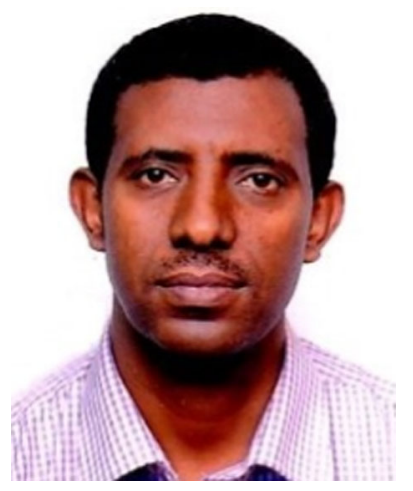

Kindie Tesfaye works at CIMMYT-Ethiopia, based in Addis Ababa. Prior to joining CIMMYT, he served in various capacities at Haramaya University and led several projects and supervised many MSc and $\mathrm{PhD}$ students. Kindie has conducted research on crop modelling, climate change, agricultural water management, agronomy, and plant physiology, and published widely in peer reviewed journals. His current research focuses on modelling the impacts of climate change and assessing adaptation options at several geospatial scales. He holds a PhD in Agricultural Meteorology from the University of The Free State in South Africa.

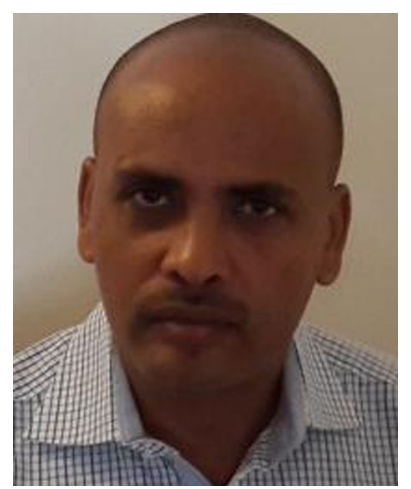

Menale Kassie is a scientist (Development Economist) based at CIMMYT-Kenya. Since he joined CIMMYT in 2010, he has been coordinating the socioeconomic components of the program "Sustainable Intensification of Maize-Legume Cropping Systems for Food Security in Eastern and Southern Africa (SIMLESA)" supported by the Australian government through the Australian Center for International Agricultural Research (ACIAR). Menale is also currently project leader of the Adoption Pathways Project, also funded by ACIAR. This project focuses on establishing panel data in five African countries in order to understand the drivers of adoption of technologies and their impacts in a dynamic perspective. Menale's research focuses on adoption and impact of crop and natural resource management technologies on rural household welfare using advanced cross-section-panel econometrics and mathematical programming models. He has analysed the contribution of sustainable land management technologies to agricultural productivity and production risks and the contribution of maize, wheat, groundnut and pigeonpea technology to food security and poverty relief.

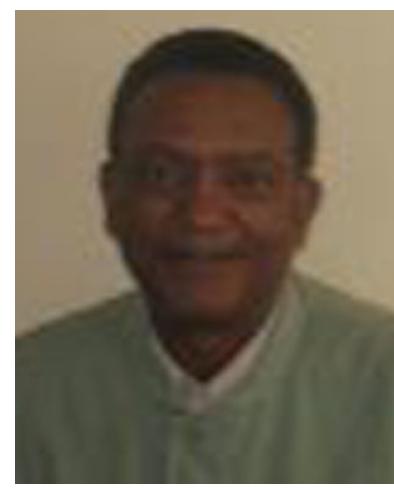

Gezahegn Bogale is breeder and team leader for maize research in the low-moisture areas at EIAR Melkassa Research Center in Ethiopia. He has more than 30 years of experience in maize research and development and has widely published on the subject. Gezahegn has released close to a dozen drought tolerant maize varieties during his long career He obtained his BSc in plant science from Haramaya University (1983), MSc in plant breeding from London University, Wye College (1994) and $\mathrm{PhD}$ in plant breeding from the University of The Free State, South Africa. 


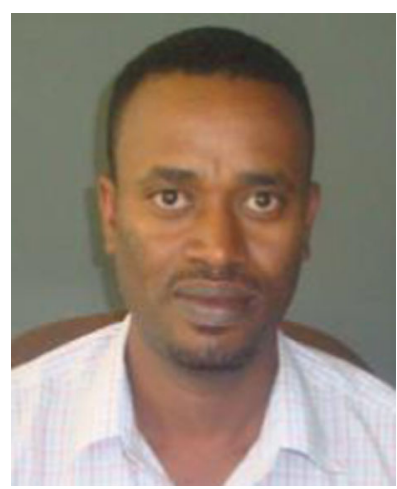

Berhanu Tadesse is affiliated to EIAR where he has worked as maize breeder in different capacities. Currently he is a $\mathrm{PhD}$ candidate at the University of The Free State, South Africa, and visiting scientist at CIMMYT-Kenya, where he is conducting his $\mathrm{PhD}$ thesis research. Before starting his PhD in February 2014, Berhanu served as maize breeder and national maize research coordinator (July 2011 - August 2013). In the same period, he was actively involved in various collaborative research projects led by CIMMYT and other organizations, including AGRA and ASARECA to address the issue of food security in Ethiopia. He has published widely on Ethiopian agriculture in peer reviewed journals and workshop proceedings. He has wide ranging research interests, which include breeding dual purpose maize for food-feed to benefit farmers in mixed-farming systems, development of nitrogen use efficient maize germplasm resistant to multiple biotic stresses, including maize lethal necrosis, and the use of modern biotech tools for accelerating gain from maize breeding. He obtained his BSc in plant sciences (2003) and MSc in plant breeding/agriculture (2009), both from Haramaya University, Ethiopia.

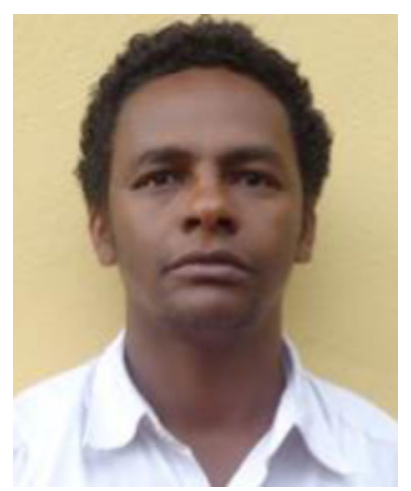

Tolera Keno is currently leading the National Maize Research Program at EIAR. Tolera's career began with completing a BSc degree majoring in plant sciences in 2006 from Hawassa University in Ethiopia. He was appointed as a junior researcher for EIAR working on maize breeding and genetics. He then joined Haramaya University and obtained his MSc in Plant Breeding in 2013. He also received the Bill and Melinda Gates Foundation Scholarship and did a Master of Agriculture

(MAg) degree majoring in Cereal Rust Pathology and Genetics from The University of Sydney, Australia. Tolera is interested in the way crop plants defend themselves against biotic and abiotic stresses that pose serious threats to global food security. 